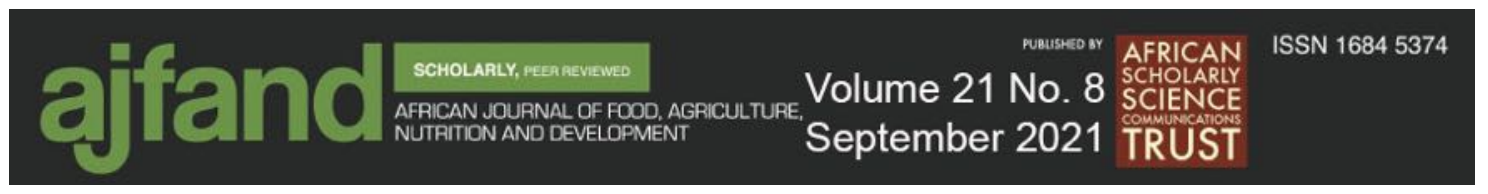

Afr. J. Food Agric. Nutr. Dev. 2021; 21(8): 18435-18449 ～https://doi.org/10.18697/ajfand.103.19855

\title{
FACTORS ASSOCIATED WITH ADOPTION OF INDIGENOUS BISCUIT PROCESSING TECHNOLOGY BY MOTHERS OF SCHOOL-GOING CHILDREN IN OGUN STATE, NIGERIA
}

\author{
Ayansina $\mathrm{SO}^{1}$, Adeola $\mathrm{AA}^{2 *}$, Fasoyiro $\mathrm{SB}^{3}$ and SA Famakinde ${ }^{4}$
}

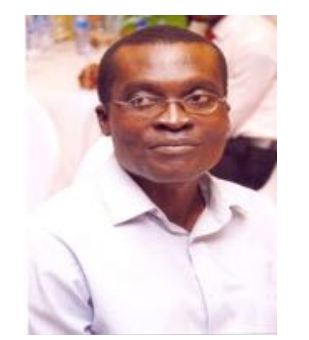

Abiodun A. Adeola

*Corresponding author email: adeolaroni@yahoo.com

${ }^{1}$ Department of Agricultural Administration, Federal University of Agriculture, Abeokuta, Nigeria

${ }^{2}$ Food and Nutrition Research Programme, Institute of Food Security, Environmental Resources and Agricultural Research, Federal University of Agriculture, Abeokuta, Nigeria

${ }^{3}$ Product Development Programme, Institute of Agricultural Research and Training, Obafemi Awolowo University, Ile-Ife

${ }^{4}$ Livestock Research Programme, Institute of Food Security, Environmental Resources and Agricultural Research, Federal University of Agriculture, Abeokuta, Nigeria 


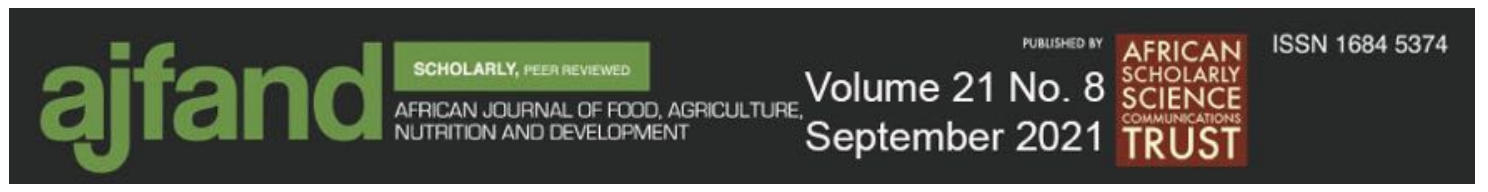

\begin{abstract}
Wheat is the conventional flour in biscuit manufacture. However, the use of wheat is not economical due to the fact that huge foreign reserve is used in its importation in Nigeria. In addition, wheat-based foods are associated with celiac disease, hence the use of non-wheat crops like tubers and legumes in biscuit processing is desirable. A previous study had developed a nutritionally improved biscuit from underutilized crops, such as sweet potato, cooking banana and pigeon pea. The present study examined factors associated with adoption of the indigenous biscuit processing technology using non-wheat flours by mothers of school going children in Ogun State, Nigeria. Amultistage sampling procedure was utilized to select 120 respondents from the list of 1,123 registered farmers in 10 extension blocks in Ogun State. A questionnaire was used to collect data on the socioeconomic characteristics of respondents. Respondents were taught the various stages of biscuit processing through demonstration. Knowledge about the various stages of biscuit processing was measured on a 5-point Likert Scale. The five points used were: extremely understood, moderately understood, somewhat understood, slightly understood and not understood. Level of adoption indicates the psychological stages that an individual passes through before making a final decision to use a particular innovation. Adoption Level was thus measured on Knowledge, Persuasions, Decision, Confirmation and Continuation decision. Data were analyzed using Analysis of Variance, Chi square, and Pearson Product Moment Correlation. Results revealed the mean age of respondents to be $40.35 \pm 10.33$ years. Most respondents were traders, and the highest educational qualification was National Diploma (2.5\%). The main sources of agricultural information were radio (64.2\%) and extension agents $(60 \%)$. There were high adoption rates in baking/production $(87.7 \%)$ and flour blending $(85.5 \%)$. Reasons for technology adoption were affordability $(80.8 \%)$, availability of ingredients $(81.7 \%)$ and relative advantage $(80.8 \%)$. Adoption of technology was associated with age $(\mathrm{r}=0.284, \mathrm{p}<0.05)$, quality of technology delivery $(\mathrm{r}=0.267, \mathrm{p}<0.05)$, marital status $\left(\chi^{2}=1.081, \mathrm{p}<0.05\right)$ and membership of association $\left(\chi^{2}=12.055, \mathrm{p}<0.05\right)$. In conclusion, effective adoption of technology could be achieved among young married mothers.
\end{abstract}

Key words: Adoption, biscuit, wheat, non-gluten flour, sweet potato, cooking banana, pigeon pea, nursing mothers 


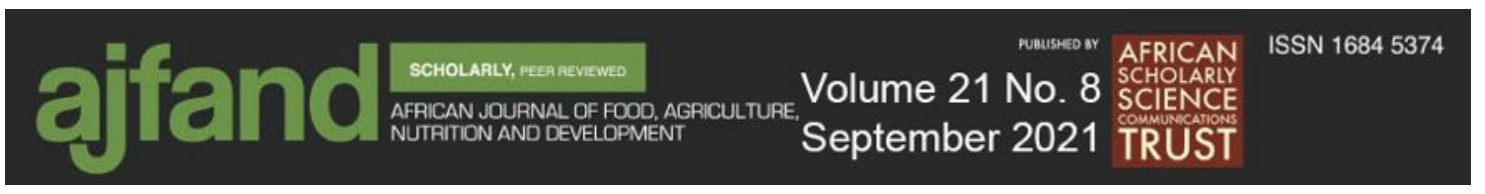

\section{INTRODUCTION}

Convenience foods have gained such a global prominence that they serve as possible means of supplying society's nourishment [1]. These foods could come in the form of hand-held snacks or full meals. The adoption of urban lifestyle by Nigerians has resulted in the popularity of convenience foods by all age groups [1]. Biscuits are flourbased, shelf- stable crispy convenience foods. The use of composite flour obtained from indigenous crops in biscuit manufacture is especially desirable in developing economies, such as Nigeria. Apart from conserving the nation's foreign reserve, such flours have the potential of contributing positively to the health of consumers. In recent times, the linkage of wheat-based foods with celiac disease has generated concern, and the use of non-wheat crops such as roots/tubers, legumes and fruits as substitutes to wheat is being advocated [2]. Sweet potato (Ipomea batatas Lam.) is an important starchy crop in the world, especially in developing countries [3]. It could be regarded as a climate-smart crop due to its ability to tolerate high temperatures, low fertility soil and drought conditions [3]. It is rich in starch, vitamins, minerals, dietary fiber and bioactive compounds, but low in protein and lipid. Sweet potato possesses antioxidant, antitumor, anti-inflammatory and anti-diabetic properties [3]. Flour from sweet potato has been suggested as a substitute to wheat flour, to lower cost of baked goods and also reduce imports of wheat [4]. Products of sweet potato flour include bread, doughnut, biscuits, muffins, breakfast cereals and complementary foods $[5,6]$.

Cooking banana was introduced in Nigeria by the International Institute of Tropical Agriculture in order to mitigate the menace of black sigatoka, a fungal leaf spot disease [5]. Other desirable agronomic qualities of cooking banana include lodging/wind resistance, drought tolerance, early ratooning capacity, short duration, as well as high bunch yield [5]. All of these qualities make cooking banana survive extreme conditions which are not conducive for plantain and desert banana. In south west Nigeria, cooking banana is known as 'ogede bello'. It has been reported to possess similar pulp weight as some cultivars of plantain [6]. It is still underutilised because of its limited application in product development, although Falade and Oyeyinka [6] reported that its flour has potential as a bakery ingredient.

Pigeon pea [Cajanus cajan (L.) Millspaugh] is the sixth most important legume crop in the world [7]. However, in West Africa, pigeon pea is a minor crop although it plays a key role in the sustenance of smallholders in Benin, Nigeria and Ghana [7]. Pigeon pea is desirable in alleviating malnutrition in developing countries as the mature seed has been reported to contain $18.8 \%$ protein, $53 \%$ starch, $2.3 \%$ fat, $6.6 \%$ crude fibre, 120.8 $\mathrm{mg} / 100 \mathrm{~g}$ calcium, $122.0 \mathrm{mg} / 100 \mathrm{~g}$ magnesium, $3.9 \mathrm{mg} / 100 \mathrm{~g}$ iron and $2.3 \mathrm{mg} / 100 \mathrm{~g}$ zinc [8]. As a perennial shrub, pigeon pea is advantageous over annual legumes in a number of ways such as high tolerance of drought stresses, high biomass productivity, soil fertility improvement, adaptability to wide range of soil types and textures (though it grows best on well-drained medium heavy loams), possibility of several harvests, untapped potential for improvement both in quantity and quality [7,9]. Pigeon pea is a versatile crop grown primarily as a vegetable in some parts of the world, Africa inclusive [9]. In rural parts of Nigeria, it is cooked and eaten just like cowpeas. Pigeon 


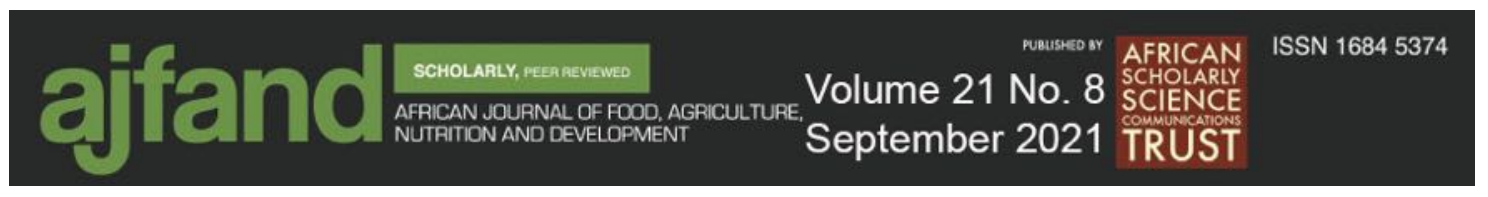

pea has been reported to improve the nutritional value of food formulations such as noodles, pasta, complementary foods and baked goods $[9,10]$.

Composite flours of sweet potato, cooking banana and pigeon pea contain attributes that are desirable for alleviating malnutrition in Nigeria and developing new food formulations [4]. Biscuits produced from the composite flour contained higher protein, total dietary, and energy contents than the conventional wheat flour. The process technology for the biscuit involved blending of ingredients to form soft dough, kneading, rolling, cutting, baking, cooling and packaging. The method of the biscuit manufacture was designed for home production by the rural dwellers. In order to exploit the potential of the improved biscuit in promoting health, there is need to transfer the process technology to consumers.

Adoption is a concept which refers to the acceptance and continuous decision to use an idea or practice by a single unit of a potential audience [11]. In the developing world, new agricultural technologies are predominantly characterized by low and slow adoption, adding to the frustration of researchers, development practitioners, policy makers and donors [12]. The compatibility of the new agricultural technologies with existing resources, practices and technologies influences adoption. The adoption process involves a sequence of sub-decisions on when to try out the new technology, when to adopt, the intensity of adoption, and whether or not to fully replace the old with the new technology [12]. The processes of adoption involve such stages as Knowledge, Persuasion, Decision, Confirmation and Continuation, Decision. The adoption of improved technology is influenced by various factors such as personal characteristics, traditional beliefs, ease of the technology, institutional and socioeconomic factors [11]. Adoption of improved technology may impact positively on the socio-economic aspects and nutritional wellness of rural dwellers [13]. Studies on adoption of agricultural technology provide bases for improving the efficiency of technology generation, assessing the effectiveness of technology transfer as well as its suitability to local environment [5]. It is against this backdrop that this study was evolved to assess adoption of improved non-gluten biscuit processing technology by mothers of school-aged children in Ogun State.

\section{METHODOLOGY}

\section{Study sites}

The study was carried out in Ogun State, Nigeria, particularly under the jurisdiction of Ogun State Agricultural Development Programme (OGADEP) that came into existence in February 1986. It is one of the first seven Multi-State Agricultural Development Projects (ADPs), which took off effectively in 1987 [21]. Like other ADPs in Nigeria, OGADEP enjoys the tripartite funding of the World Bank, the Nigerian Federal Government and the Ogun state Government. For administrative purposes, Ogun State is divided into four zones: Abeokuta, Ilaro, Ijebu-ode, and Ikenne. Each zone is managed by a Zonal Extension Officer. Each Local Government of the State is also divided into two block- offices and each block office into cells. Finally, respondents were selected from 16 cells out of 54 which represented about $30 \%$ of the total cells in the study area. Each block is controlled by a Block Extension Supervisor and each cell 


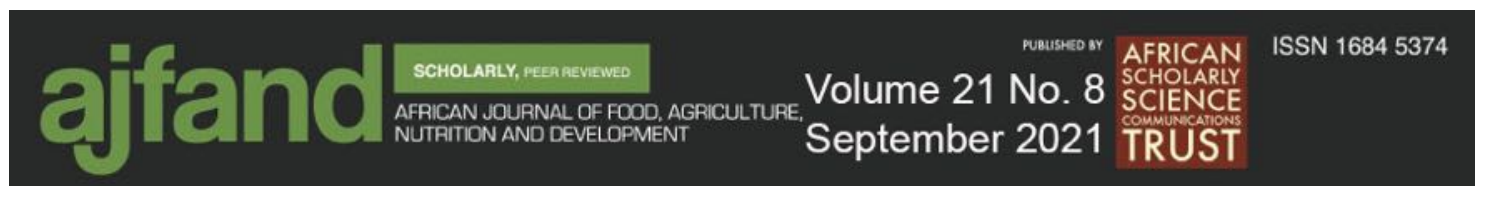

by a Village Extension Agent. The ADP as an organisation is run through a management system giving room for effective implementation of adoption process and other extension services which are often conceptualized as an educational process which promotes learning. The ADP makes use of combination of findings in biological sciences research and principles of social sciences to effect desirable changes in knowledge, skills, attitudes and practices of farmers in and out of school setting.

\section{Respondents Sampling Process}

A three- stage sampling procedure was employed to select respondents among the mothers of school-going children in Ogun State [14]. In stage one, as depicted in table 1 , there was a purposive selection of ten (10) extension blocks from twenty (20) Local Government Areas in the four (4) existing zones (Abeokuta, Ikenne, Ijebu-ode and Ilaro) of the State. In the second stage, $16(28.1 \%)$ of the 57 cells in the State were randomly selected; five from Abeokuta, two from Ikenne, five from Ijebu-ode and four from Ilaro. Finally, 30 mothers of school-going children were selected from 10, 6, 10 and 6 villages (Cells) in Abeokuta, Ikenne, Ijebu-ode and Ilaro zone respectively. Thus, a total number of one hundred and twenty (120) respondents selected from the list of 1,123 on the ADP farmers' register in thirty-two (32) villages were trained and interviewed for the delivery and adoption of the process technology of gluten-free biscuit.

\section{Data Collection Instruments}

The instrument utilized for the purpose of this research work was a questionnaire. The questionnaire used in this study consisted of about 55 questions separated into six sections: Section A was composed of eight socio-economic variables related with the theme of the study, and Section B was composed of seven items on the technology knowledge index of flour production which sought how well respondents understood the processing technology.

Section C sought information on the adoption indices of improved biscuits/flour on the various stages of production of banana, pigeon pea, sweet potato blended flour and final baking/ production processes. In section D, information was sought on reasons for the technology adoption which was captured on Cheap/Economical, Relative advantage, Production Mechanism/Divisibility, Availability of material, Simplicity of the method, Compatibility with Culture. In Section E, Constraints to adoption was measured on inadequate finance/Capital investment, High cost of baking ingredients, Non-acceptability/Palatability of the product, Inadequate/high cost of required facility and complexity to baking technology respectively.

In order to ascertain the validity of the instrument used for data collection for the study, the instruments' content was securitized through an expert's judgment, and to check the overall reliability of the questionnaire it was subjected to the Cronbach's Alpha of internal consistency [19]. The value obtained for the Cronbach's Alpha coefficient was 0.78 , which proves that the reliability of the instrument used for this investigation was high enough to produce a valid and reliable result. 


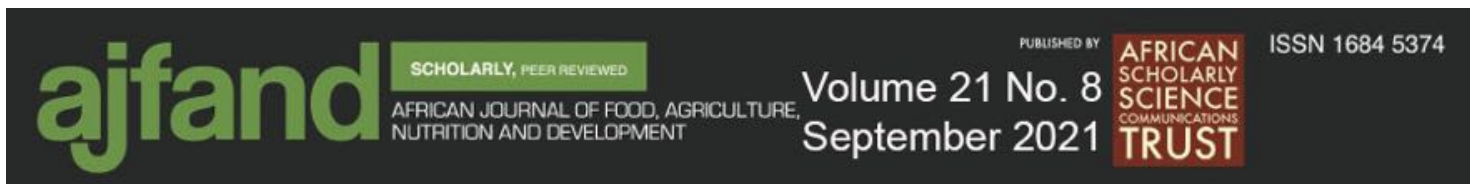

Knowledge acquisition index of the processing technology

Knowledge acquisition index is responsible for identifying, acquiring and storage of new knowledge that will be useful in decision making process to undertake a particular task. It specifically refers to series of tasks required to be performed for accomplishment of a process of a technology which in this study are: blending of composite flour, kneading, rolling into sheet, cutting into shapes, baking, cooling and packaging. The modified method of Ogundile [15] was used. Likert Scale self-designed questionnaire was used to collect the data where 'Extremely Understood' $=5$, 'Somewhat Understood' $=3$ and 'Slightly Understood' $=1$. The mean score is 2.5 meaning that any score above this is held to be significant.

\section{Adoption index and Reasons for the process technology}

This was done according to Jibowo [16]. Adoption Index is the series of psychological stages which an individual passes in the process of making a final decision to utilize a particular innovation. This psychological stage runs through the path of knowledge, persuasion, decision to use, and confirmation and continuation of the technology operation while the obvious reasons were also used to test why they adopted the technology. On a check back on the technology delivered to the respondents, some months after the technology delivery to the mothers of school-age children, an evaluation process was staged to examine the adoption status of the technology.

\section{Design and Data Analysis}

The study was a survey type aiming at analysis, interpretation and empirical generalization of the data collected from the specified population of mothers of school going children. Specifically, it examined the distribution, incidence, and interaction of study variables so as to achieve the objectives of the study. In the quest to achieve this, a quantitative research methodology was placed on the method of surveys and application of statistical test with SPSS was utilized. Furthermore, a descriptive analysis such as frequency counts, percentages, means $(\bar{X})$ and measure of variability were utilized to present the results on descriptive levels. Chi-square and Pearson Product Moment Correlation (PPMC) analysis were employed to assess the relationship of the adoption of the technology with marital status, sources of information, membership of association, age and knowledge levels of the respondents.

\section{RESULTS AND DISCUSSION}

\section{Socio-demographic characteristics of respondents}

In order to describe the socioeconomic characteristics of the respondents, data were captured and presented on variables such as age, marital status occupation characteristics, educational level, sources of agricultural information and income level. Participation and utilization of improved practices and new technologies vis-à-vis development has been a subject of discussions in many instances most especially among the farmers and women folk in the rural settings [20]. The adoption of innovation particularly is mostly influenced by various factors such as personal characteristics, traditional beliefs, simplicity of the technology, institutional and socioeconomic factors [11]. As further shown on table 2, 38.3\% and $23.0 \%$ of the respondents were between 31-40 and 41-50 years, respectively. The mean age of the 


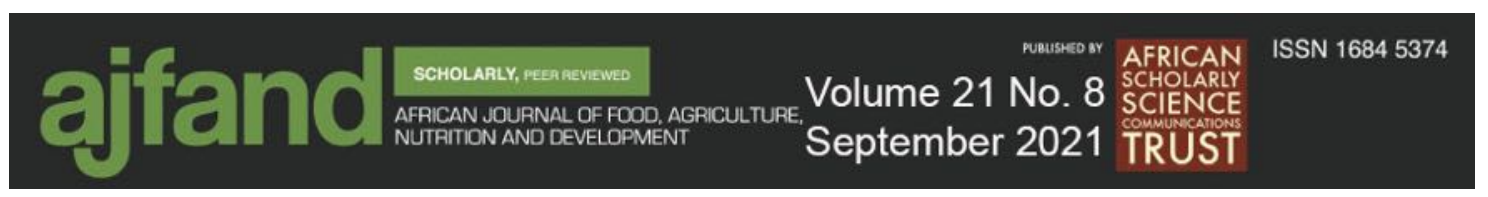

respondents was 40.3 years $(\mathrm{SD}=10.33)$. This is an indication that respondents were still agile and able individuals expected to be favourably disposed to change, vulnerable to knowledge acquisition and hence adoption of innovation such as non-gluten biscuit processing technologies [17,18]. Majority $(63.3 \%)$ of the respondents were married and $33.3 \%$ were single mothers. Results on occupation characteristics revealed that $35.8 \%$ were traders, $20.0 \%$ engaged in sewing/weaving while $19.2 \%$ and $8.3 \%$ earned livelihood in farming and catering services. As further depicted in table 2, 28\% were school certificate holders, $10.8 \%$ of the respondents possessed either Ordinary National Diploma or National Certificate of Education while $2.5 \%$ and $8.0 \%$ had bachelor and post graduate degrees respectively. According to table 2, important sources of agricultural/home making information were radio, extension agents, farmers around, other sources included researchers and neighbours, and cooperative/social club. The monthly income of the majority $(52.5 \%)$ of the respondents varied between $\$ 30,000$ (USD 62.5) and $\$ 40,000$ (USD 83.3).

\section{Knowledge acquisition index of the processing technology}

As shown on table 3 , results revealed that rolling into sheet $(\bar{X}=3.87)$ was the most understood task followed by cooling of the final product $(\bar{X}=3.84)$. Other stages as understood were cutting into different shapes $(\bar{X}=3.70)$, kneading $(\bar{X}=3.60)$, and blending of the composite flour $(\bar{X}=3.57)$ accordingly. These results indicated that there was a high understanding of the various tasks involved in the technology process among the respondents (Mothers of School- going Children). The respondents embraced the innovation with interest and all enthusiasm probably because it directly affected the welfare of their children and also the possibility of commercializing the product for their family upkeep [22].

\section{Adoption index and Reasons for the process technology}

As depicted on table $4 \mathrm{a}$, adoption process was operationalized on knowledge, persuasion, and decision to use, confirmation and continuation of the technology operation. Results revealed that $85.8 \%$ of the respondents adopted the technology and continued the method involved in production of banana, pigeon pea, sweet potato flour, and blending of composite flour while $87.7 \%$ adopted and continued the use of the method in baking and actual biscuit production process. Furthermore, reasons for adoption of the technology were also sought among the respondents (table $4 \mathrm{~b}$ ). Results revealed that $81.7 \%$ of the respondents adopted the technology due to availability of material/ingredient involved and simplicity of the methods. Other reasons behind the high adoption were cheap/economical (80.8\%), relative advantage/nutritious $(80.8 \%)$, production mechanism/divisibility (79.2\%) and compatibility with their culture (75.0\%). In this regard, it is affirmed that the respondents were favourably disposed to the technology and continuous utilization of the innovation because when the technology was being introduced to them, it was observed that they were happy and very interested to have it in order to improve the welfare of their children and probably making money from its commercial production in the future [22].

\section{Testing of Research Hypotheses}

Hypotheses were set for the study in order to establish the relationships between the dependent (Adoption of study technology) and independent variables such as 


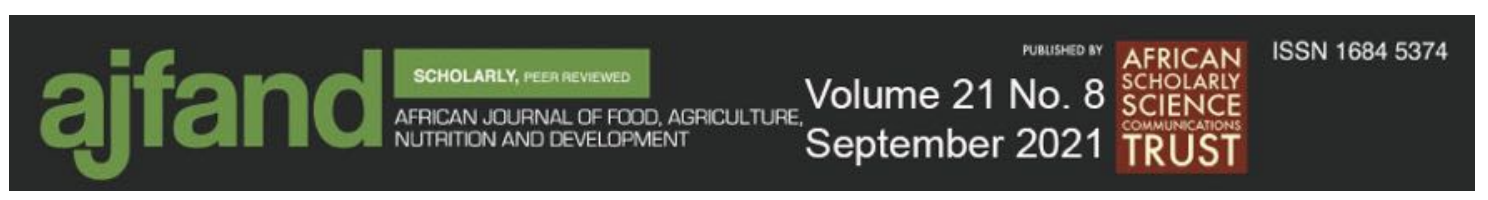

socioeconomic characteristics of the respondents, knowledge level at the various stages involved in the technology processing and production. In doing this Chi-square analysis, PPMC and ANOVA were employed to test the relationships among the variables and the technology adoption.

As shown on table 6 , Chi-square analysis revealed a significant relationship $(\mathrm{p}<0.05)$ between marital status $\left(\chi^{2}=1.081\right)$, membership of association $\left(\chi^{2}=12.055\right)$ and adoption of the technology. This implies that being a married individual and belongingness to some associations will positively enhance and assist quick adoption of innovation. Table 7 revealed positive and significant association $(\mathrm{p}<0.05)$ between age of the respondents $(r=0.284)$, quality of technology delivery process $(r=0.267)$ and adoption of the technology. This result agreed with Nwaru [17] who found that middle age individuals among rural dwellers are more receptive to innovative ideas and hence, more likely to adopt new technologies than old farmers. Okonkwo et al. [18] also stated that technology adoption and utilization increase with quality and varieties of training delivery methods by the scientists and agricultural extension officers involved.

\section{CONCLUSION}

The overall development of any nation requires a dynamic and systematic generations of useful ideas and appropriate technologies. And for such to be useful, there is a need for its proper adoption among the target population. Adoption of appropriate technology is expected to make a positive impact on the socioeconomic status of the respondents, human dietary processing and the overall development of rural dwellers. Tested hypotheses revealed that marital status, age, membership of association and quality of technology delivery process enhanced utilization of non-gluten biscuit processing technology. There were also differences in the level of adoption of the technology among the respondents in the different zones of the study area. It is however recommended that effective delivery of the biscuit technology could be achieved among the married young mothers. Extension agents, researchers and all change agents are enjoined to be more proactive in further researches on food science and agricultural production systems. These will go a long way to improve the overall status and wellbeing of the rural dweller through a vibrant and result oriented extension delivery process.

\section{ACKNOWLEDGEMENTS}

The authors acknowledge the Tertiary Fund, Nigeria for providing the IBR grant (TetFund IBR 2015/2016 Merged) through the Federal University of Agriculture Abeokuta for this research work. 


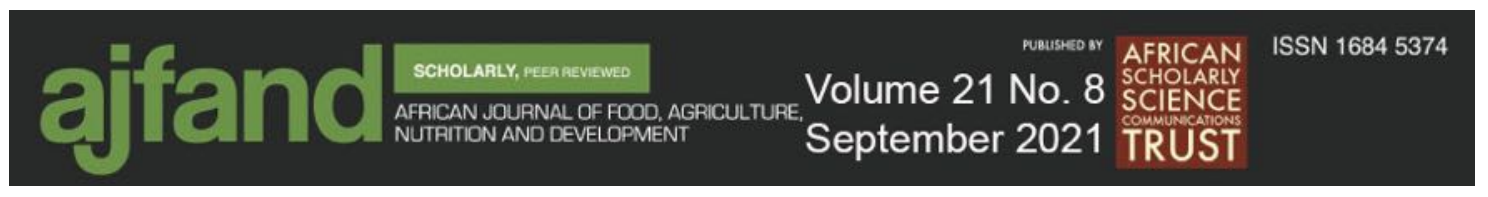

Table 1: Sample frame of respondents

\begin{tabular}{|c|c|c|c|c|c|c|}
\hline $\begin{array}{l}\text { ADP ZONES IN } \\
\text { OGUN STATE }\end{array}$ & $\begin{array}{l}\text { No of } \\
\text { Blocks }\end{array}$ & $\begin{array}{l}50 \% \text { of Block } \\
\text { Selected }\end{array}$ & $\begin{array}{l}\text { No of } \\
\text { Cells* }\end{array}$ & $\begin{array}{l}30 \% \text { of Cell } \\
\text { Selected }\end{array}$ & $\begin{array}{l}\text { No of } \\
\text { Selected } \\
\text { Villages* }\end{array}$ & $\begin{array}{l}\text { Selected } \\
\text { Respondents }\end{array}$ \\
\hline Abeokuta & 6 & 3 & 18 & 5 & 10 & 30 \\
\hline Ikenne & 4 & 2 & 8 & 2 & 6 & 30 \\
\hline Ijebu-Ode & 6 & 3 & 15 & 5 & 10 & 30 \\
\hline Ilaro & 4 & 2 & 13 & 4 & 6 & 30 \\
\hline Total & 20 & 10 & 54 & 16 & 32 & 120 \\
\hline
\end{tabular}

Source: - Field Survey, 2018

*Random and Purposive methods were used in the selection of cells and villages 


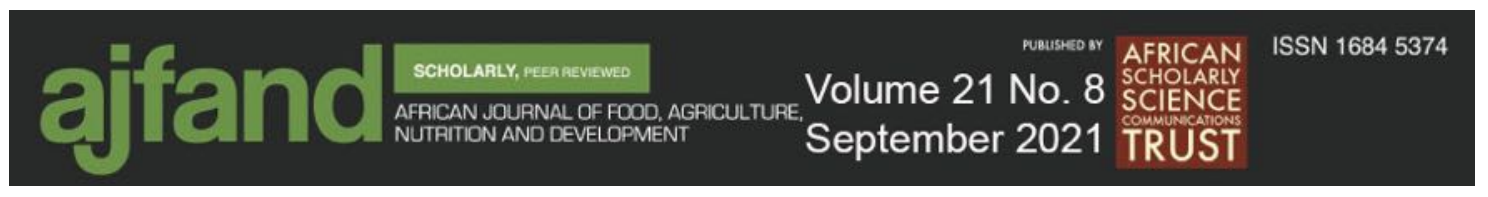

Table 2: Socio-demographic characteristics of respondents

\begin{tabular}{|c|c|c|c|}
\hline Variables & Frequency & Percentages (\%) & Mean/ S.D N=120 \\
\hline \multicolumn{4}{|l|}{ Age (actual age in years) } \\
\hline Less than or equal to 30 & 23 & 19.2 & \\
\hline $31-40$ & 46 & 38.3 & $40.35 / 10.33$ \\
\hline $41-50$ & 28 & 23.3 & \\
\hline $51-60$ & 18 & 15.0 & \\
\hline $61-70$ & 5 & 4.2 & \\
\hline \multicolumn{4}{|l|}{ Marital Status } \\
\hline Single Mother & 40 & 33.3 & \\
\hline Married & 76 & 63.3 & \\
\hline Divorced & 4 & 3.4 & \\
\hline \multicolumn{4}{|l|}{ Occupation } \\
\hline Farming & 23 & 19.2 & \\
\hline Agro-processing & 4 & 3.3 & \\
\hline Trading & 43 & 35.8 & \\
\hline Sewing/Tailoring/Weaving & 24 & 20.8 & \\
\hline Catering & 10 & 8.3 & \\
\hline Fishing & 1 & 8 & \\
\hline Small chop biz & 1 & 8 & \\
\hline Student & 10 & 8.3 & \\
\hline Teaching & 4 & 3.3 & \\
\hline \multicolumn{4}{|l|}{ Educational level } \\
\hline No formal education & 25 & 20.8 & \\
\hline Primary education & 41 & 34.2 & \\
\hline Secondary education & 34 & 28.3 & \\
\hline Teacher's grade test & 3 & 2.5 & \\
\hline $\begin{array}{l}\text { Ordinary National Diploma/National Certificate of } \\
\text { Education/Higher National Diploma }\end{array}$ & 13 & 10.8 & \\
\hline Bachelor degree & 3 & 2.5 & \\
\hline
\end{tabular}




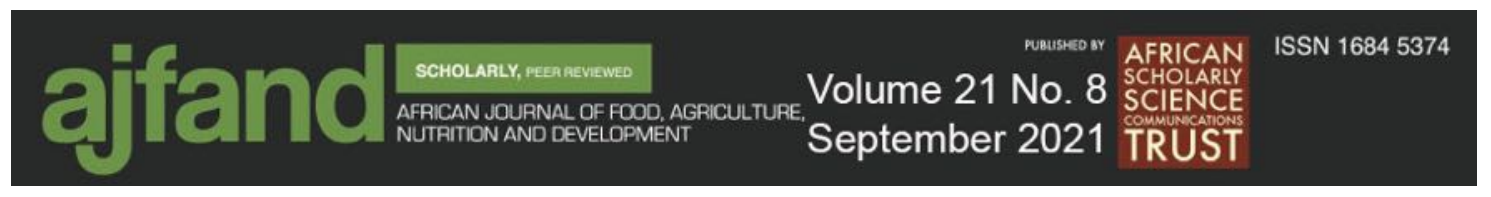

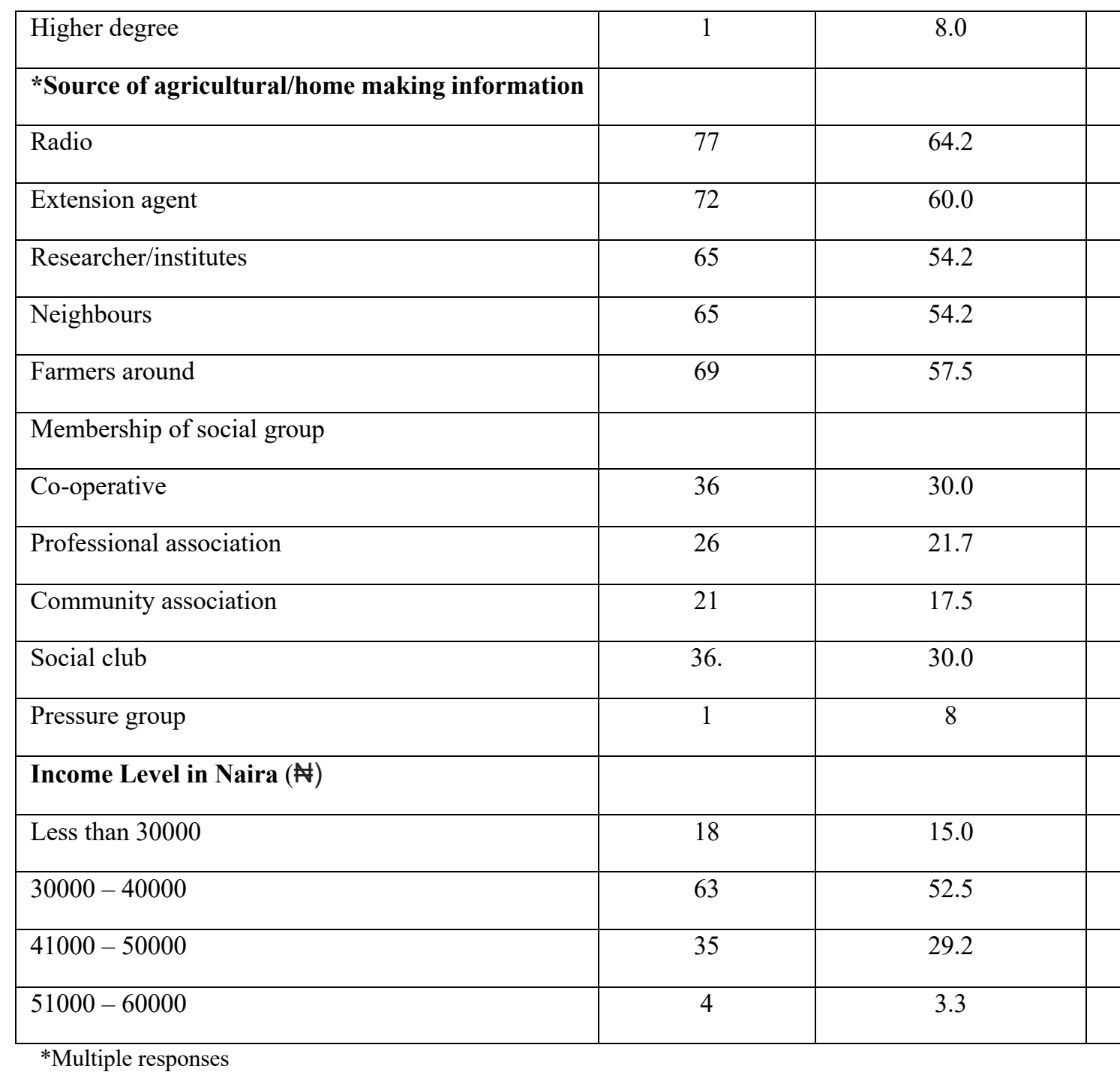

Table 3: Knowledge acquisition index of the indigenous biscuit technology process

\begin{tabular}{|l|l|l|l|l|l|l|}
\hline Biscuit & EU (\%) & MU (\%) & SOU (\%) & SLU (\%) & NU (\%) & Mean \\
\hline Blending of composite flour & $56(46.7)$ & $11(9.2)$ & $14(11.7)$ & $23(19.2)$ & $16(13.3)$ & 3.57 \\
\hline Kneading & $51(42.5)$ & $18(15.0)$ & $16(13.3)$ & $22(18.3)$ & $13(10.8)$ & 3.60 \\
\hline Rolling into sheet & $58(48.3)$ & $10(8.3)$ & $12(10.0)$ & $29(24.2)$ & $11(9.2)$ & 3.87 \\
\hline Cutting into shapes & $61(50.8)$ & $10(8.3)$ & $12(10.0)$ & $26(21.7)$ & $11(9.2)$ & 3.70 \\
\hline Baking of biscuits & $56(46.7)$ & $10(8.3)$ & $30(25.0)$ & $23(19.2)$ & $1(0.8)$ & 3.81 \\
\hline Cooling of the final product & $63(52.5)$ & $18(15.0)$ & $9(7.5)$ & $17(14.2)$ & $13(10.8)$ & 3.84 \\
\hline Packaging in polythene & $85(70.8)$ & $21(17.5)$ & $6(5.0)$ & $6(5.0)$ & $2(1.7)$ & 4.51 \\
\hline
\end{tabular}

EU (Extremely Understood); MU (Moderately Understood); SOU (Somewhat Understood); SLU (Slightly Understood); NU (Not Understood) 


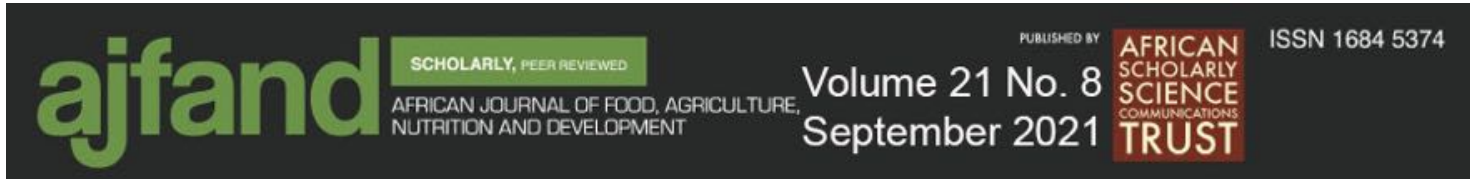

Table 4: Adoption index of the indigenous biscuit technology

\begin{tabular}{|l|l|l|l|l|l|}
\hline Improved Biscuit & $\begin{array}{l}\text { Knowledge } \\
(\mathbf{\%})\end{array}$ & $\begin{array}{l}\text { Persuasion } \\
(\mathbf{\%})\end{array}$ & $\begin{array}{l}\text { Decision } \\
(\mathbf{\%})\end{array}$ & $\begin{array}{l}\text { Confirmation } \\
(\mathbf{\%})\end{array}$ & $\begin{array}{l}\text { Continuation } \\
(\mathbf{\%})\end{array}$ \\
\hline Banana flour production & $120(100.0)$ & $120(100.0)$. & $105(87.5)$ & $103(85.8)$ & $103(85.8)$ \\
\hline Pigeon pea flour production & $120(100.0)$ & $120(100.0)$ & $103(85.8)$ & $103(85.8)$ & $103(85.8)$ \\
\hline Sweet potato flour production & $120(100.0)$ & $120(100.0)$ & $103(85.8)$ & $103(85.8)$ & $103(85.8)$ \\
\hline Blending of flour & $120(100.0)$ & $120(100.0)$ & $103(85.8)$ & $103(85.8)$ & $103(85.8)$ \\
\hline Baking/production & $120(100.0)$ & $120(100.0)$ & $104(86.7)$ & $104(86.7)$ & $104(87.7)$ \\
\hline
\end{tabular}

Table 5: Reasons for adoption of the indigenous biscuit technology

\begin{tabular}{|l|l|l|}
\hline Reasons & Yes (\%) & No (\%) \\
\hline Cheap/economical & $97(80.8)$ & $23(19.2)$ \\
\hline Relative advantages (Nutritious) & $96(80.8)$ & $24(20.0)$ \\
\hline Production mechanism/divisibility & $95(79.2)$ & $25(20.8)$ \\
\hline Availability of materials involved & $98(81.7)$ & $22(18.3)$ \\
\hline Simplicity of method involved & $88(73.3)$ & $32(26.7)$ \\
\hline Compatibility with culture & $90(75.0)$ & $30(25.0)$ \\
\hline
\end{tabular}

Table 6: Test of association between socio-demographic characteristics of the respondents and the adoption of the indigenous biscuit technology process

\begin{tabular}{|l|l|l|l|}
\hline Variables & X-value & Df & P -value \\
\hline Marital status & 1.081 & 3 & 0.002 \\
\hline Occupation & 7.233 & 8 & 0.512 \\
\hline Educational level & 2.538 & 6 & 0.864 \\
\hline Radio & 1.085 & 1 & 0.297 \\
\hline Extension agent & 1.382 & 1 & 0.240 \\
\hline Researcher & 2.151 & 1 & 0.142 \\
\hline Neighbour & 9.403 & 1 & 0.026 \\
\hline Farmers around & 0.421 & 1 & 0.517 \\
\hline Membership of association & 12.055 & 4 & 0.017 \\
\hline
\end{tabular}

$\mathrm{S}=$ Significant at $\mathrm{p}<0.05 ; \mathrm{NS}=$ Not significant at $\mathrm{p}>0.05$ 


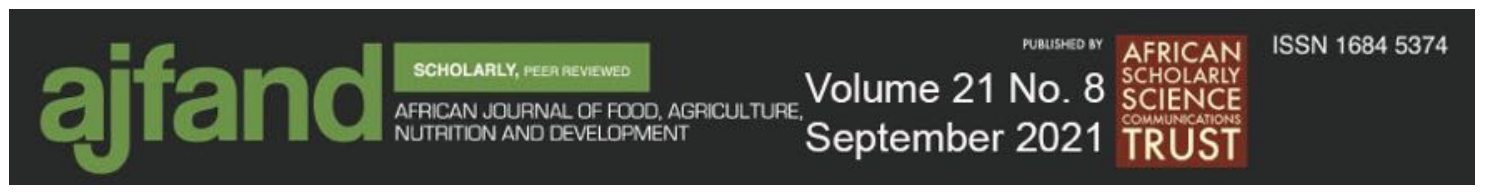

Table 7: Correlation test of significance between age, income, technology of delivery and Adoption of indigenous biscuit Technology Process

\begin{tabular}{|l|l|l|}
\hline Variables & R-value & P -value \\
\hline Age & 0.284 & 0.002 \\
\hline Income level & 0.093 & 0.315 \\
\hline Technology delivery & 0.267 & 0.006 \\
\hline
\end{tabular}

$\mathrm{S}=$ Significant at $\mathrm{p}<0.05 ; \mathrm{NS}=$ Not significant at $\mathrm{p}>0.05$ 


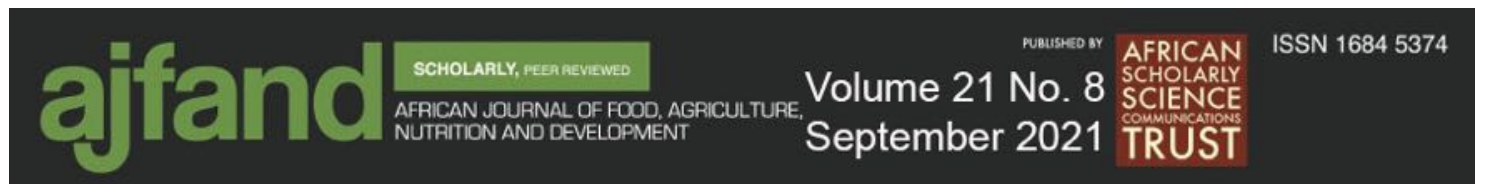

\section{REFERENCES}

1. Tillotson JE Convenience Foods. In: Caballero B, LC Trugo and PM Finglas (Eds). Encyclopedia of Food Sciences and Nutrition. London: Academic Publishers, 2003; 1616-1622.

2. Nwanekezi EC Composite Flours for Baked Products and Possible Challenges A Review. Niger. Food J. 2013; 31 (2): 8 - 17.

3. Cui R and F Zhu Physicochemical and Functional Properties of Sweet potato Flour. J. Sci Food Agric. 2011; 99 (10): 4624 - 4634.

4. Ohizua ER, Adeola AA, Idowu MA, Sobukola OP, Afolabi TA, Ishola R, Ayansina SO, Falomo A and TO Oyekale Nutrient Composition, Functional and Pasting Properties of Unripe Cooking Banana, Pigeonpea and Sweet potato Flour Blends. Food Sci. Nutri. 2017; 5 (3): 750-762.

5. Lemchi JI, Tshiunza M, Onyeka $\mathbf{U}$ and A Tenkouano Factors Driving the Adoption of Cooking Banana Processing and Utilisation Methods in Nigeria. Afr. J. Biotechnol. 2005; 4 (11): 1335-1347.

6. Falade KO and SA Oyeyinka Colour, Chemical and Functional Properties of Plantain Cultivars and Cooking Banana as Affected by Drying Method and Maturity. J. Food Process. Pres. 2015; 39 (6): 816 - 828.

7. Ayenan MAT, Ofori K, Ahoton LE and A Danquah Pigeon pea [(Cajanus cajan (L.) Millsp.)] Production System, Farmers' Preferred Traits and Implications for Variety Development and Introduction in Benin. Agric. Food Secur. 2017; 6:48. DOI 10.1186/s40066-017-0129-1.

8. Saxena KB and RV Kumar Quality Nutrition through Pigeonpea - A Review. Health 2010; 2:1335-44.

9. Mula MG and KB Saxena Lifting the Level of Awareness on Pigeonpea: A Global Perspective. International Crops Research Institute for the Semi-Arid Tropics, Patancheru. 2010: 60-64.

10. Kaushal P, Vivek Kumar V and HK Sharma Comparative Study of Physicochemical, Functional, Antinutritional and Pasting Properties of Taro (Colocasia esculenta), Rice (Oryza sativa) Flour, Pigeonpea (Cajanus cajan) Flour and Their Blends. LWT - Food Sci. Technol. 2012; 48:59-68.

11. Ehinmowo OO and AI Fatuase Adoption of Improved Cassava Processing Technologies by Women Entrepreneur in South-west, Nigeria. World J. Agric. Res. 2016; 4 (4): 109-113. 


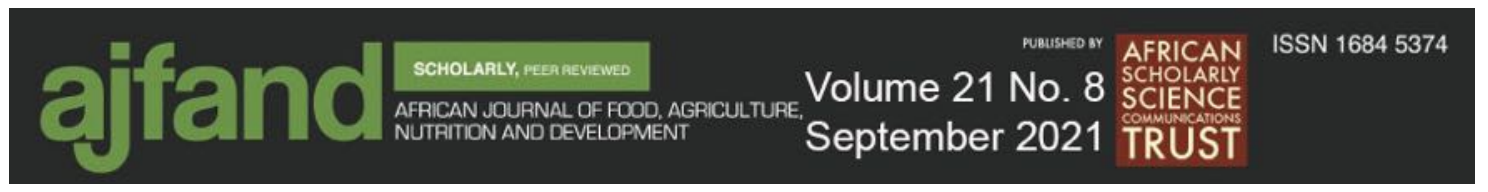

12. Yigezu YA, Mugerab A, El-Shaterc T, Aw-Hassana A, Piggind C, Haddade A, Khalile $\mathbf{Y}$ and $\mathbf{S}$ Lossf Enhancing Adoption of Agricultural Technologies Requiring High Initial Investment Among Smallholders. Technol Forecast. Soc Change 2018; 134: 199-206.

13. Mohammed F, Boateng $\mathbf{S}$ and $\mathbf{S}$ Al-hassan Effects of Adoption of Improved Sheabutter Processing Technology on Women's Livelihoods and Their Microenterprise Growth. Am. J. Human. Soc. Sci. 2013; 1 (4): 244-250.

14. Ivande PD, Olaolu MO and EM Igbokwe Technological Changes in Farming Among the Tiv Farming Households in Nigeria. J. Agric. Ext. 2019; 23 (1): 1-12.

15. Ogundile OP, Bishop SA, Okagbue HI, Ogunniyi PO, and AM Olanrewaju Factors Influencing ICT Adoption in Some Selected Secondary Schools in Ogun State, Nigeria. Int. J. Emerg Technol 2019; 14 (10): 62-74.

16. Jibowo G Essential of Rural Sociology. Gbemi Sodipo Press Limited, Abeokuta, Nigeria. 2000.

17. Ogunwale AB Socioeconomic Factors Associated with Alley Farming Technology in Osun State. PhD Thesis. Obafemi Awolowo University, Ile-Ife, Osun State, Nigeria. 1998.

18. Okunade EO and IO Oladosu Rating of Extension Teaching Methods for Training Female Farmers in Osun State, Nigeria. Agricultural Extension Society of Nigeria. 2006: 42-50.

19. Cho E and S Kim Chronbach's Coefficient Alpha: Well Known but Poorly Understood. Organ. Res.Methods 2015; 18 (2): 207-230.

https://doi.org/10.1177/1094428114555994

20. Adenugba AO and NO Raji-Mustapha The Role of Women in Promoting Agricultural Productivity and Developing Skills For Improved Quality of Life In Rural Areas. IOSR J. Eng. 2013; 3(8): 51-58.

21. World Bank. Agricultural Development Projects in Nigeria. Independent Evaluation Group (IEG). The World Bank, Washington DC. 2001.

22. Ihimodu II The impact of the better Life Programmes on the Economic Status of Women. Ibadan: IFRA/Africa Book Buildings, 1996; 13-20. 